УДК $811.111[36+42]$

\author{
Strelchenko N.S. \\ eglantine@ukr.net \\ https://orcid.org/0000-0002-2585-2563 \\ $\mathrm{PhD}$, Senior Lecturer of the Department of \\ English Philology and Translation, \\ Kyiv National Linguistic University \\ Kyiv, Ukraine
}

\title{
PATTERNS OF LEXICAL COHESION REALIZED BY ECHO QUESTIONS IN ENGLISH CONVERSATIONAL DISCOURSE
}

Being common in conversational discourse, echo questions constitute its integral part (Carter \& McCarthy, 2006, p. 199). In the literature, definitions of echo questions involve repetition / paraphrase of the preceding utterance as "they repeat, directly or in paraphrase, all or part of what someone else has just said, either to confirm it or to express surprise or disbelief" (Teschner \& Evans, 2007, p. 64). Besides, echo questions have been studied as a means of increasing discourse coherence by resolving misunderstanding (Strelchenko, 2017), ensuring cohesion within adjacency pairs and by lexico-grammatical means of realizing semantic relations: repetition, ellipsis, substitution, synonyms / antonyms, and conjunction (Стрельченко, 2018). Thus, it seems worthwhile to explore the regularities in repetition and paraphrase from the viewpoint of discourse cohesion, which makes this research topical.

The object of analysis is echo questions in English conversational discourse and its subject matter is constituted by lexical cohesive devices employed in echo questions functioning in English conversational discourse. The aim of the present study is to identify the patterns of use of lexical cohesive devices realized by echo questions in English conversational discourse represented by fragments of British and American fiction films, which served as material for the research. The methods employed are descriptive, contextual, and discourse analyses.

Developing her theory of textual coherence and cohesion, R. Hasan put forward the following types of general lexical cohesive devices: repetition, synonymy, hyponymy, antonymy, and meronymy (Halliday \& Hasan, 1989, p. 80-82).

The functions of repetition vary depending on the lexical make-up of the echo question itself and the neighbouring utterances. An element from the preceding utterance may be repeated to inquire about further details:

(1) Miss Lemon: There's a lady to see you, Mr Poirot.

Hercule Poirot: A lady?

Miss Lemon: A client. Her name's Mrs Todd (The adventure of the Clapham cook). 
Poirot's echo question is called for by the ambiguous referring expression a lady used by Miss Lemon and serves to find out the identity of the person mentioned.

Aspects of the referent situation which interest the speaker may be established by means of a special echo question which follows the repeated element from the preceding utterance:

(2) Poirot: In my book, as you say, Monsieur, everyone is a suspect. And on this Friday evening everyone is invited to a party, including yourself and your sister, Mademoiselle Theresa.

Charles: A party? Who is throwing it?

Poirot: Well, your aunt, Emily Arundel (Dumb witness).

In this communicative situation, Charles's echo question A party? shows his surprise and doubts as to whether a party is appropriate in the context of investigating his aunt's murder, and he goes on to inquire who the organizer is; as for Charles's emotions, they can be recognized only with reference to the context and nonverbal cues. In contrast, the following discourse fragment illustrates expression of a negative emotion within an echo question:

(3) Inspector Frost: What's going on?

Superintendent Mullett: He's got explosives. He's been placing them on the machinery.

Inspector Frost: How the hell did he get explosives?

Superintendent Mullett: Mr Jameson! Tell the inspector how he got hold of explosives.

Les Jameson: Charlie keeps a spare set of keys for the detonator cabinet and the explosives store hidden, you know. Just in case (Close encounters).

Repetition of the neutral lexical unit explosives (Longman, 2003, p. 550) is used in a special echo question to find out more details about the incident, while Inspector Frost's surprise and irritation are expressed by means of an emphatic structure How the hell?, which is marked "not polite" (Longman, 2003, p. 759), containing a swear word hell (Oxford, 2003, p. 203).

Apart from inquiring about specific information, repetition is also used to encourage the interlocutor to continue speaking, especially if he / she feels hesitant to provide information which may turn out irrelevant or implicate other people concerned:

(4) Poirot: Tell me, Mademoiselle, you were not present at the hostel last night?

Patricia Lane: No, I'd been out. I came back late.

Chief Inspector Japp: So, you didn't see anything that might help us?

Patricia Lane: Well, there was one thing. I don't know if it means anything, but as I got back, I noticed somebody coming out of the window onto the fire escape.

Chief Inspector Japp: The fire escape?

Patricia Lane: I don't want to get anyone into trouble.

Chief Inspector Japp: Miss Lane! 
Patricia Lane: I know. It was Sally, Sally Finch. I've often thought there was something strange about her. And it was her. I'm sure (Hickory Dickory Dock).

Chief Inspector Japp's echo question, repeating the last part of Patricia Lane's utterance, urges her to provide more details as her evidence may prove important in the course of the investigation.

Another function of repetition is to introduce an answer to the interlocutor's question, gain time to think, and create suspense:

(5) Sally Finch: But who was it? Which one of them is the killer?

Poirot: The killer? Ah. The killer was the person who felt compelled to steal the light bulbs (Hickory Dickory Dock).

Similarly, an echo question containing repetition may precede the expression of disagreement (dispreferred next action (Pomerantz, 1984, p. 64)):

(6) Miss Lemon: Well, Florence will be glad it's all over.

Poirot: All over, Miss Lemon? Non. It is now that I fear that it may begin (Hickory Dickory Dock).

Hercule Poirot has successfully solved a number of mysterious cases of theft at the student's hostel belonging to Miss Lemon's sister; however, he anticipates more serious crimes to follow. Poirot's echo question containing repetition and direct address serves to make his reply polite and somewhat soften the negative impact of his prediction.

Disagreement may pertain both to the communicative proper and metacommunicative (Чхетиани, 1987, с. 6) planes of communication, in the latter case questioning the appropriateness of a certain nominative unit. Consider the following exchange:

(7) Count Corini: Something terrible has just happened to me.

Jessica Reid: What?

Count Corini: Only once before has that happened. When I held the little Norwegian girl in my arms. The first time I was ever in love. Do you feel my heart beating?

Jessica Reid: No.

Count Corini: You don't?

Jessica Reid laughing: Your technique is really amazing.

Count Corini: Technique? You mean you do not believe me? But I tell you things like this happen only once, maybe twice in the lifetime.

Jessica Reid: No doubt. Shall we go on to dance?

Count Corini: By all means (Always Goodbye).

The dictionary meaning of technique is 'a particular way of doing something, especially one in which you have to learn special skills' (Oxford, 2003, p. 1555); yet Count Corini takes issue with the situational connotative meaning of negative evaluation, trying to convince Jessica Reid of the sincerity of his intentions.

Depending on its pragmatic function, paraphrasing in echo questions involves ideographic / stylistic and contextual synonyms. 
In service encounters, the use of high-flown and bookish vocabulary in echo questions imparts a professional touch to the conversation:

(8) Lady Frances Derwent: I believe a friend of mine was down here the other day. Mr Bassington-ffrench. He was looking for a house.

Real estate agent: Making inquiries about various properties with a view to purchase? He was obliged to return to town the next day, so he couldn't view many of the houses we have to offer. Since he left, one or two highly suitable properties have come onto the market. I've sent him on particulars. To Merroway Court, Staverley, Hants. But I've had no reply (Why didn't they ask Evans?).

By substituting the neutral word house with its formal equivalent property ('a building or buildings and the surrounding land' (Oxford, 2003, p. 1182)) and using contextual synonyms looking for instead of making inquiries about with a view to purchase the estate agent aims at sounding serious and unbiased, not engaging in gossip, as his echo question does not expect Lady Frances Derwent's answer.

In the communication of colleagues, who discuss a third party, avoidance of colloquial and evaluative connotations allows remaining neutral:

(9) Poirot: Charles and Theresa, Bella and Jacob, even Wilhemina and Dr Grainger. I'd say all are capable of murder, mon ami.

Hastings: Quite a list of suspects, Poirot.

Poirot: Which is not complete. You forget the sisters Tripp.

Hastings: Oh, those two? Well, they're batty, yes, but not killers, surely. witness).

Poirot: Well, what is murder, but a kind of madness, mon ami? (Dumb

Poirot's rhetorical echo question, used to make a generalized statement, represents a paraphrase involving a change of part-of-speech characteristics: an informal adjective batty ('slightly crazy in a harmless way' (Oxford, 2003, p. 106)) is substituted by an abstract stylistically neutral noun madness ('serious mental illness' (Longman, 2003, p. 989)); killers, focusing on the agentive aspect of the referents, corresponds to the abstract noun murder emphasizing a sense of intention to take someone's life (Longman, 2003, p. 1083).

In contrast to remaining neutral, echo questions may be used to ensure clarity instead of ambiguous, euphemistic formulations.

(10) Mr Porter: Your father availed himself of some of the bank's assets without first observing the conventional forms.

Miss Dove: He stole? Are you saying that my father stole?

Mr Porter: Let us say he borrowed (Good morning, Miss Dove).

In this communicative situation, a bank president, $\mathrm{Mr}$ Porter, is informing Miss Dove that her late father committed embezzlement. In doing so, he introduces the problem by saying how inconvenient he feels to raise the subject, which is confirmed by another euphemistic formulation he borrowed. The formal expression avail yourself of something ('to make use of something, especially an opportunity' (Oxford, 2003, p. 82)) as such does not imply any 
impropriety and without first observing the conventional forms is ambivalent either, which makes Miss Dove use a blunt formulation.

Hyponymy ("a hierarchical organization of language elements based on genus-species relations" (Новиков, 1998, с. 104)) is realized as general specific nomination.

(11) Commander Chantry: What's the matter, Val?

Valentine Chantry: I don't know. That drink tasted queer.

Commander Chantry: The pink gin? This?

Valentine nods (Triangle at Rhodes).

Commander Chantry's echo question names a particular type of a drink, ensuring its unique identification. Similarly, in the following situation the echo question performs a specifying function:

(12) Inspector Sullivan: Do you happen to know who his next of kin is?

Father Brown: Jane Milton.

Inspector Sullivan: Professor Milton is Vince Lennon's next of kin?

Father Brown: I'm afraid so (The last man).

The referring expression Professor Milton, being gender-neutral, may be viewed as more general than the proper name Jane Milton; however, they belong to different semantic groups (common class nouns and proper nouns).

Meronymy ("a type of paradigmatic relations between language units which represent a whole and its parts (holonym and partonyms)" (Селіванова, 2010 , c. 385)) in echo questions pertains to abstract rather than concrete objects. As has been suggested in the literature, an activity regulated by a certain script / scenario has "stages, phases, discrete periods, or subactivities" as its partonyms (Winston, Chaffin \& Herrmann, 1987, p. 426). The following exchange is realized within "murder investigation" scenario.

(13) Poirot: The case is closed.

Hastings: You mean you've caught the murderer?

Poirot: There is no murderer (The king of clubs).

Closing a case usually implies establishing the identity of the culprit, which represents the final stage of solving a crime by a private detective. Structurally dissimilar to the stimulus utterance, the echo question represents its partonym: "catching the murderer" is part of "closing a case".

Antonymy is realized in the form of a paraphrase, sometimes spanning several turns:

(14) Zeke Kelso: Miss Randall, I don't think we should expose your cat's relationship with us at this time. I'd like to remain as inconspicuous as possible.

Patti Randall: You mean you don't want everyone in the neighbourhood to know who you are or what you're doing?

Zeke Kelso: Exactly. I don't know why, but people tend to become overstimulated when they discover an FBI man in the neighbourhood. Tends to interfere with the quiet, orderly process of investigation.

Patti Randall: Oh, hmm. 
Zeke Kelso: Especially in kidnap cases. You see, this places the life of the kidnapped victim into additional jeopardy.

Patti Randall: You mean we've gotta be careful not to generate too much heat? The kidnappers are liable to chicken out, kill Miss Miller, dispose of the remains, and take off?

Zeke Kelso: Uh, that's one way you'd put it, yes (That darn cat).

Apart from differing part-of-speech characteristics, the negated antonymic formulations in the stimulus utterances and echo questions differ stylistically: remain inconspicuous and quiet, orderly process of investigation ensure a professional matter-of-fact tone appropriate for an FBI agent, whereas (not) generate too much heat sounds rather sensational, being uttered by a young impressionable woman.

Thus, lexical cohesive devices demonstrate a number of regularities. Repetition may involve a single lexical unit from the preceding utterance, its inclusion into a special echo question, or combination with emotionally coloured vocabulary. As regards hyponymy, echo questions contain specification of the general notions from the stimulus utterance. Meronymy pertains to abstract entities, parts / aspects of which are established by echo questions. Antonyms in echo questions may be negated and differ in terms of their connotations. Further research may involve studying lexical cohesion realized by echo questions in different discourse practices.

\section{Список використаної літератури}

1. Новиков Л. А. Гипонимия. Языкознание. Большой энциклопедический словарь / гл. ред. В. Н. Ярцева. 2-е изд. Москва, 1998. С. 104. 2. Селіванова О. О. Лінгвістична енциклопедія. Полтава : Довкілля-К, 2010. 844 с. 3. Стрельченко Н. С. Питання-перепити крізь призму когезії діалогічного дискурсу. Україна і світ: діалог мов та культур : матеріали міжнар. наук.-практ. конф. (Київ, 11-13 квітня 2018 р.). Київ, 2018. С. 321-323. 4. Чхетиани Т. Д. Лингвистические аспекты фатической метакоммуникации : автореф. дисс. ... канд. филол. наук : 10.02.04. Киев, 1987. 24 с. 5. Always Goodbye : motion picture / directed by S. Lanfield. Twentieth Century Fox Film Corporation, 1938. 6. Carter R., McCarthy M. Cambridge grammar of English. Cambridge : Cambridge University Press, 2006. 973 p. 7. Close encounters : motion picture / directed by P. Harrison. ITV Productions, 2003. 8. Dumb witness : motion picture / directed by E. Bennett. Carnival Film \& Television, 1996. 9. Good morning, Miss Dove : motion picture / directed by H. Koster. Twentieth Century Fox Film Corporation, 1955. 10. Halliday M. A. K., Hasan R. Language, context, and text: aspects of language in a social-semiotic perspective. Oxford : Oxford University Press, 1989. 126 p. 11. Hickory Dickory Dock : motion picture / directed by A. Grieve. Carnival Film \& Television, 1995. 12. Longman dictionary of contemporary English / edited by C. Fox et al. 4th edition. Harlow : Pearson Education Limited, 2003. 1949 p. 13. Oxford advanced learner's dictionary of current English / edited 
by S. Wehmeier. 6th edition. Oxford : Oxford University Press, 2003. $1791 \mathrm{p}$. 14. Pomerantz A. Agreeing and disagreeing with assessments: some features of preferred/dispreferred turn shapes. Structures of social action: Studies in conversation analysis / edited by J. M. Atkinson, J. Heritage. Cambridge, 1984. P. 57-101. 15. Strelchenko N. Echo questions as a means of building coherence in conversational discourse. Lege artis. Language yesterday, today, tomorrow. The Journal of University of SS Cyril and Methodius in Trnava. Warsaw : De Gruyter Open, 2017. Vol. II(1). P. 336-378. 16. Teschner R. V., Evans E. E. Analyzing the grammar of English. 3rd edition. Washington, D. C. : Georgetown University Press, 2007. 248 p. 17. That darn cat : motion picture / directed by R. Stevenson. Walt Disney Productions, 1965. 18. The adventure of the Clapham cook : motion picture / directed by E. Bennett. London Weekend Television, 1989. 19. The king of clubs : motion picture / directed by R. Rye. Picture Partnership Productions, 1989. 20. The last man : motion picture / directed by J. Greening. BBC, 2015. 21. Triangle at Rhodes : motion picture / directed by R. Rye. Picture Partnership Productions, 1989. 22. Why didn't they ask Evans? : motion picture / directed by J. Davies, T. Wharmby. London Weekend Television, 1980. 23. Winston M. E., Chaffin R., Herrmann D. A taxonomy of part-whole relations. Cognitive science. 1987. Vol. 11. P. 417-444.

\section{References}

1. Novikov, L. A. (1998). Hyponymy. In V. N. Jarceva (Ed.), Jazykoznanie. Bol'shoj jenciklopedicheskij slovar' [Linguistics. A comprehensive encyclopedic dictionary] (p. 104). (2nd edition). Moscow: Bol'shaja Rossijskaja jenciklopedija [in Russian]. 2. Selivanova, O. O. (2010). Linhvistychna entsyklopediia [Linguistic encyclopedia]. Poltava: Dovkillia-K [in Ukrainian]. 3. Strelchenko, N. S. (2018). Pytannia-perepyty kriz pryzmu kohezii dialohichnoho dyskursu [Echo questions through the prism of cohesion of conversational discourse]. Ukraina i svit: dialoh mov ta kultur : Conference proceedings (pp. 321-323). Kyiv: Vyd. tsentr KNLU [in Ukrainian]. 4. Chhetiani, T. D. (1987). Lingvisticheskie aspekty faticheskoj metakommunikatsii [Linguistic aspects of phatic metacommunication] (Candidate dissertation abstract). Kyiv State Pedagogical Institute of Foreign Languages, Kyiv [in Russian]. 5. Zanuck, D. F. (Producer), \& Lanfield, S. (Director). (1938). Always Goodbye [Motion picture]. USA: Twentieth Century Fox Film Corporation. 6. Carter, R., \& McCarthy, M. (2006). Cambridge grammar of English. Cambridge: Cambridge University Press. 7. Bates, R. (Producer), \& Harrison, P. (Director). (2003). Close encounters [Motion picture]. UK: ITV Productions. 8. Eastman, B. (Producer), \& Bennett, E. (Director). (1996). Dumb witness [Motion picture]. UK: Carnival Film \& Television. 9. Engel, S. G. (Producer), \& Koster, H. (Director). (1955). Good morning, Miss Dove [Motion picture]. USA: Twentieth Century Fox Film Corporation. 10. Halliday, M. A. K., \& Hasan, R. (1989). Language, context, and text: Aspects of language in a 
social-semiotic perspective. Oxford: Oxford University Press. 11. Eastman, B. (Producer), \& Grieve, A. (Director). (1995). Hickory Dickory Dock [Motion picture]. UK: Carnival Film \& Television. 12. Longman dictionary of contemporary English (2003). Harlow: Pearson Education Limited. 13. Oxford advanced learner's dictionary of current English (2003). (6th edition). Oxford: Oxford University Press. 14. Pomerantz, A. (1984). Agreeing and disagreeing with assessments: Some features of preferred/dispreferred turn shapes. In J. M. Atkinson \& J. Heritage (Eds.), Structures of social action: Studies in conversation analysis (pp. 57101). Cambridge: Cambridge University Press. 15. Strelchenko, N. (2017). Echo questions as a means of building coherence in conversational discourse. Lege artis. Language yesterday, today, tomorrow. The Journal of University of SS Cyril and Methodius in Trnava, 2(1), pp. 336-378. 16. Teschner, R. V., \& Evans, E. E. (2007). Analyzing the grammar of English (3rd edition). Washington, D. C.: Georgetown University Press. 17. Disney, W. (Producer), \& Stevenson, R. (Director). (1965). That darn cat [Motion picture]. USA: Walt Disney Productions. 18. Eastman, B. (Producer), \& Bennett, E. (Director). (1989). The adventure of the Clapham cook [Motion picture]. UK: London Weekend Television. 19. Eastman, B. (Producer), \& Rye, R. (Director). (1989). The king of clubs [Motion picture]. UK: Picture Partnership Productions. 20. Meyrick, C. (Producer), \& Greening, J. (Director). (2015). The last man [Motion picture]. UK: BBC. 21. Eastman, B. (Producer), \& Rye, R. (Director). (1989). Triangle at Rhodes [Motion picture]. UK: Picture Partnership Productions. 22. Wharmby, T. (Producer), \& Davies, J. (Director). (1980). Why didn't they ask Evans? [Motion picture]. UK: London Weekend Television. 23. Winston, M. E., Chaffin, R., \& Herrmann, D. (1987). A taxonomy of part-whole relations. Cognitive science, $11,417-444$.

Стрельченко Н.С. Типи лексичної когезї̈, що реалізуються питаннями-перепитами в англомовному діалогічному дискурсі

Статтю присвячено дослідженню лексичних засобів когезії: повторення, перефразування, синонімії, гіпонімії, меронімії та антонімії в питаннях-перепитах (визначальною рисою яких $\epsilon$ повторення / перефразування попередньої репліки) в англомовному діалогічному дискурсі. Було з'ясовано, що повторення в питаннях-перепитах може стосуватися однієї лексичної одиниці з висловлення співрозмовника, передбачати ii включення до спеціального питання-перепиту або поєднання 3 емоційно забарвленою лексикою. Функції повторення включають запит додаткових важливих деталей, заохочення співрозмовника продовжувати спілкування, отримання часу на роздуми та створення напруги перед тим, як надати відповідь, зменшення категоричності реакції на висловлення співрозмовника, а також незгоду / сумнів щодо конотацій певної номінативної одиниці. Перефразування в питаннях-перепитах включає ідеографічні / стилістичні та 
контекстуальні синоніми. За умови гіпонімії, питання-перепити спрямовані на уточнення родових понять / елементів широкої семантики 3 репліки-стимулу. Меронімія стосується абстрактних сутностей, частини / характеристики яких встановлюються питаннями-перепитами. Антоніми в питаннях-перепитах можуть вживатися у формі заперечення, а також відрізнятися в аспекті конотацій.

Ключові слова: питання-перепити, лексична когезія, повтор, синонімія, гіпонімія, меронімія, антонімія, діалогічний дискурс.

Стрельченко Н.С. Типы лексической когезии, реализуемые вопросами-переспросами в англоязычном диалогическом дискурсе

Статья посвящена исследованию лексических средств когезии: повторения, перефразирования, синонимии, гипонимии, меронимии и антонимии в вопросах-переспросах (определяющим признаком которых является повторение / перефразирование предыдущей реплики) в англоязычном диалогическом дискурсе. Установлено, что повторение в вопросах-переспросах может охватывать одну лексическую единицу из высказывания собеседника, предусматривать ее включение в специальный вопрос-переспрос или сочетание с эмоционально окрашенной лексикой. Функции повторения включают запрос дополнительных важных деталей, поощрение собеседника продолжать общение, получение времени на размышления и создание напряжения перед тем, как предоставить ответ, снижение категоричности реакции на высказывание собеседника, а также несогласие / сомнение относительно коннотаций определенной номинативной единицы. Перефразирование в вопросах-переспросах включает идеографические / стилистические и контекстуальные синонимы. В случае гипонимии вопросы-переспросы направлены на уточнение родовых понятий / элементов широкой семантики из реплики-стимула. Меронимия охватывает абстрактные сущности, части / характеристики которых устанавливаются вопросамипереспросами. Антонимы в вопросах-переспросах могут употребляться в форме отрицания, а также отличаться коннотациями.

Ключевые слова: вопросы-переспросы, лексическая когезия, повтор, синонимия, гипонимия, меронимия, антонимия, диалогический дискурс.

\section{Strelchenko N.S. Patterns of lexical cohesion realized by echo questions in English conversational discourse}

The article aims at establishing regularities in the use of lexical cohesive devices: repetition, paraphrase, synonymy, hyponymy, meronymy, and antonymy in echo questions (the defining feature of which is considered to be repetition / paraphrase of the interlocutor's utterance) functioning in English conversational discourse. Discourse fragments taken from British and American films served as data for the study, which employed descriptive, contextual, and discourse analyses. The investigation revealed that repetition in echo questions may involve a single lexical unit from the preceding 
utterance, its inclusion into a special echo question, or combination with emotionally coloured vocabulary. Functionally, repetition may aim at inquiring about further relevant details, encouraging the interlocutor to continue speaking, gaining time to think and creating suspense before giving an answer, making the response to the interlocutor's utterance less categorical as well as questioning the connotations of a certain nominative unit. Paraphrasing in echo questions involves ideographic / stylistic and contextual synonyms. As regards hyponymy, echo questions are aimed at specification of the general notions from the stimulus utterance. Meronymy pertains to abstract entities regulated by scripts or scenarios, parts / aspects of which are established by echo questions. Antonyms in echo questions may be negated and differ in terms of their connotations. The results presented in the article may be used to explore variation in the patterns of lexical cohesion in different discourse practices.

Key words: echo questions, lexical cohesion, repetition, synonymy, hyponymy, meronymy, antonymy, conversational discourse.

Стаття надійшла до редакції 24.09.2018 p.

Стаття прийнята до друку 14.04.2019 р.

Рецензент - доцент кафедри англійської філології і перекладу імені професора I. B. Корунця Київського національного лінгвістичного університету, канд.філол.наук В. Б. Скрябіна 